\title{
Short Communication: The diversity of termites along the altitudinal gradient in a Karst Area of Southern Gombong, Central Java, Indonesia
}

\author{
HERY PRATIKNYO^, ENDANG ARIYANI SETYOWATI \\ Faculty of Biology, Universitas Jenderal Soedirman. Jl. Dr. Suparno No. 63, Purwokerto Utara, Banyumas 53122, Central Java, Indonesia. \\ Tel./fax.: +62-281-625865, `email: hery.pratiknyo17@gmail.com
}

Manuscript received: 15 November 2019. Revision accepted: 30 March 2020

\begin{abstract}
Pratiknyo H, Setyowati EA. 2020. Short Communication: The diversity of termites along the altitudinal gradient in a Karst Area of Southern Gombong, Central Java, Indonesia. Biodiversitas 21: 1730-1734. A karst area of Southern Gombong at altitudes of 0$500 \mathrm{~m}$ has a porous substrate whose soil content decreases as the altitude gets higher toward the top of the hill. This area is characterized by poor soil nutrient, but it has high $\mathrm{CaCO}_{3}$ and $\mathrm{pH}$, which is not a favorable habitat for many species of termites which depend on soil substrate, as source of nutrient for community development, especially soil-feeding termites, as habitat for fungi as secondary daily diet, and as a stabilizer of the nest humidity. The aims of this research were to determine the diversity of termites along the altitudinal gradient in this karst area, and to determine the correlation between altitude and the termite diversity. The area was divided into 5 segments based on the altitudes, i.e., 0-100 m, 100-200 m, 200-300 m, 300-400 m, and 400-500 m. In each segment, a transect belt, 100 $\mathrm{m}$ long and $2 \mathrm{~m}$ wide, was made. Each transect was divided into 20 sections. Termites were sampled from living trees, branches, bark, litter and soil for 30 minutes per person in each section. The data were analyzed to determine the Shannon-Wienner diversity index $\left(\mathrm{H}^{\prime}\right)$, Shannon-Evenness index (E), and Simpson's Dominance index, and to find the correlation between the species diversity and altitude. The results showed that the termite diversity in the study site was low. Only four termite species were found with the indexes of diversity (H'), evenness (E), and dominance (D) of 1.01, 0.73 and 0.44 respectively. There was no linear correlation between termite diversity and altitude; the highest diversity was found in the middle altitudes, following the mid-domain effect model.
\end{abstract}

Keywords: Diversity, Gombong, karst, termites

Abbreviations: $\mathrm{CaCO}_{3}$ : Calcium carbonate, pH: Power of hydrogen, H': Shanon_Wienner Index, E: Shanon evenness index, D: dominance Simpson Index

\section{INTRODUCTION}

Termites are dominant invertebrate fauna of tropical land forest (Wood and Sand 1978) and their role as decomposers in terrestrial ecosystem is very important (Lee and Wood 1971; Matsumoto and Abe 1979; Yamada et al. 2005). Carbon mineralization process and nitrogen fixation during decomposition process depend on them (Yamada et al. 2005). The role of termites in their habitat is expressed in their feeding habits. At the present, at least there are four groups of termites based on their feeding habits, i.e., woodonly feeders, wood and fungi feeders, humus feeders and soil feeders (Yamada et al. 2005). The diversity (species richness and abundance) of termites inhabiting an ecosystem needs to be studied because the roles of termites on their habitat are affected by their diversity (Jones and Prasetyo 2002).

Diversity of termites is influenced by many environmental factors, such as forest canopy closure (Carrijo et al. 2009), altitudes (Gathorne-Hardy et al. (2001), air temperature and transpiration (Choosai et al. 2009). Davies et al. (2003) state that local factors such as the loss of forest canopy and forest degradation have significant impact on the diversity of termites. Dense canopy creates optimal soil humidity for termite community development (Choosai et al. 2009 ) while the loss of canopy decreases termite diversity (Carrijo et al. 2009). There is a correlation between termite diversity and vegetation density (Davies et al. 2003).

Gathorne-Hardy et al. (2001) state that altitudinal factor significantly affects the diversity of termites in tropical land forest because the metabolism processes in termites' body depend on air temperature which declines approximately $1^{\circ} \mathrm{C}$ with $100 \mathrm{~m}$-increase in altitudes. This is one reason why density of termites is higher on low land than on high land, even though some termite species may be found in altitudes higher than $3000 \mathrm{~m}$. Termites usually live optimally at air temperature of $15-38^{\circ} \mathrm{C}$ with relative humidity of $75-90 \%$ and soil $\mathrm{pH}$ of 7 . The genera Microtermes, Macrotermes, and Odontermes prefer this interval air temperature to the lower one because that level of air temperature and soil $\mathrm{pH}$ are optimal for the growth of fungi as additional diets for higher termites besides wood as the main diet ( Korb and Linsmaier 1998).

The effect of altitude on termite diversity can be studied in a karst hill in Gombong, Central Java. Previously, there had been no study of termites in this karst area, while in Mountain Slamet, which is only $40 \mathrm{~km}$ from the karst 
area, a study has found 9 genera of termites (Pratiknyo et al. 2018). We assumed that the termite diversity in the karst hill was lower than that in Mount Slamet for two reasons. First, the karst hill has a homogenous forest of teak (Tectona grandis) which shed leaves during dry season, so the sunlight can reach the forest floor, causing high air temperature, while the Mount Slamet has a mixed stand of Pinus merkusii and Recinus damara trees with dense canopy which effectively reduce sunlight reaching the forest floor. Second, the karst area is lack of soil nutrient because of the dominance of limestone under the teak stand.

The aims of this research were to determine the termite diversity at different altitudes (100, 200, 300, 400 and 500 $\mathrm{m})$ of karst area, and to know the correlation between termite diversity and altitude on the karst area of Southern Gombong, Central Java.

\section{MATERIALS AND METHODS}

\section{Study area}

This study was conducted in a karst hill of Southern Gombong, Central Java. It is a well developed porous landscape with specific conditions as a result of soluble rock development through a process of karstification. This karst hill is located next to the Indian Ocean beach in Central Java. This area covers three sub-districts, namely Rowokele, Ayah and Buayan Sub-districts. The limestone hill is $8 \mathrm{~km}$ long and $3 \mathrm{~km}$ wide with a total area of more than $40 \mathrm{~km}^{2}$, located between $7^{0} 42^{\prime} 10,91^{\prime \prime}$ and $7^{0} 42^{\prime} 4,4^{\prime \prime} \mathrm{S}$, and between $109^{\circ} 26^{\prime} 46,39^{\prime \prime}$ and $109^{\circ} 26^{\prime} 38,15^{\prime \prime} \mathrm{E}$, with altitudinal range from 0 to $500 \mathrm{~m}$. This karst area is a cockpit type, which is a karst hill having a cone shape, tight and having a bird's nest-like form, and it is one of the most interesting karst types in the world (Suhendar et al. 2018).

Materials and Methods should emphasize on the procedures and data analysis. For field study, it is better if study site is included (Figure 1).

The study area has annual rainfall of $139 \mathrm{~mm}$, air temperature $26^{-3} 31^{\circ} \mathrm{C}$, relative air humidity $78-85 \%$, canopy opening of $T$. grandis $90-100 \%$, and the thickness of the teak leaf litter $1-5 \mathrm{~cm}$ with relative humidity of the karst soil $60-75 \%$. The thin forest soil is dominated by limestone with a $\mathrm{pH}$ of 7.3 .

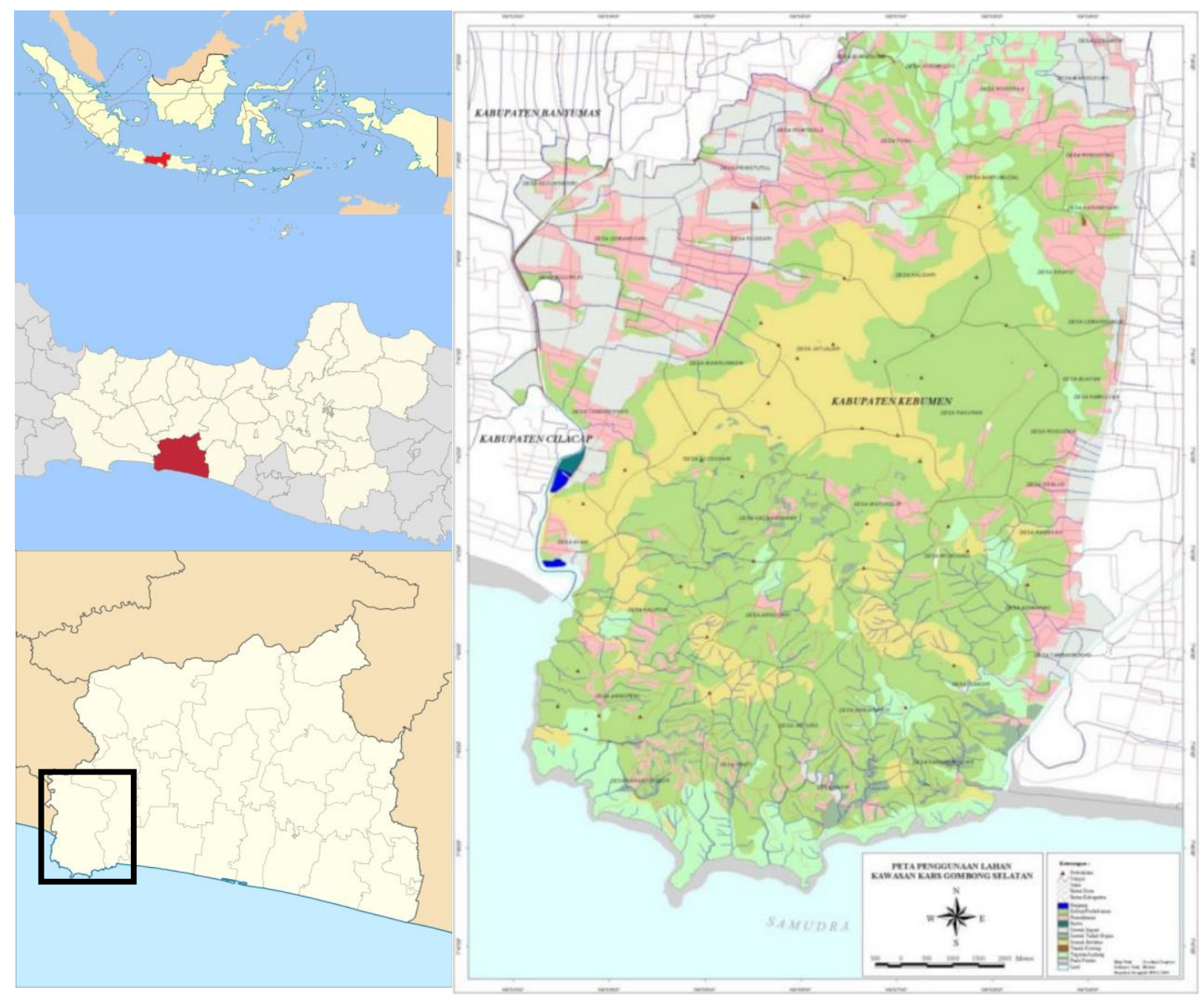

Figure 1. Location of Southern Gombong karst area in Kebumen District, Central Java, Indonesia 


\section{Data collection}

The tools used in this study were pin sets, plastic vials, altimeter, $\mathrm{pH}$ meter, termohygrometer and stereo microscopes. Termites were sampled using belt transect method, in T. grandis forest, at altitudes from 0 to500 m, divided into 5 segments. In each $100 \mathrm{~m}$-segment, a belt transect, $100 \mathrm{~m}$ long and $2 \mathrm{~m}$ wide, was made. Each belt transect was divided into 20 sections (L: $5 \mathrm{~m}, \mathrm{~W}: 2 \mathrm{~m}$ ) as sampling units. The termites were taken from the living trees, branches, bark, litter, and soil for 30 minutes per person in each section. The specimens of termites found were then kept in alcohol $70 \%$ in the plastic vials. The identification of termite specimens was done following Ahmad (1958).

\section{Data analysis}

The termite data were analyzed to determine the indexes of diversity, evenness and dominance for each 100 m segment. (Magurran 1988). The formula used was:

$$
\text { Shannon-Wiener index of diversity: } H^{s}=-\sum_{i=1}^{\infty} \text { pi (ln pi) }
$$

Where:

$\mathrm{H}^{\prime}$ : diversity index of Shannon-Wiener

pi : proportion of species i to total species

ln : normal logarithm

ni : number of individuals of species $i$

$\mathrm{N}$ : total number of all species

Shannon-Evenness index: $E=\frac{H^{0}}{\operatorname{In} S}$

Where:

E : Shannon-Evenness index

$\mathrm{H}^{\prime}$ : diversity index of Shannon-Wiener

$S$ : number species

Dominance index of Simpson: $\mathrm{D}=\sum_{i=1}^{n}(p i)^{2}$

Where:

D : dominance index of Simpson

pi : proportion of species i to total species

Correlation between species number and individual density with altitude was determined using regression analysis

\section{RESULTS AND DISCUSSION}

\section{Results}

The results showed that all of the termites found were wood feeders, consisting of higher termites (three species) and lower termites (one species). No litter-feeding and soilfeeding termites were found. Macrotermes gilvus had the highest abundance, followed by Microtermes insperatus, Schedorhinotermes javanicus and $O$. javanicus (Table 1). The highest individual density occurred in altitudes of 201$300 \mathrm{~m}$, while the lowest in altitudes of $401-500 \mathrm{~m}$.

The termite community in the karst area had low indexes of diversity, and dominance but relatively high evenness index (Table 2).

The pattern of the species number of termites in all of altitudes showed the highest number in the middle altitudes (Figure 2), and so did the individual density (Figure 3).

The regression between diversity of termites with altitude $(100,200,300,400$ and $500 \mathrm{~m}$. asl) showed low correlation $(\mathrm{R}=0.289)$.

\section{Discussion}

The condition of teak forest along altitudinal gradient of 0-500 $\mathrm{m}$ forest was dry, with air temperature of $26-31^{\circ} \mathrm{C}$, relative humidity $78-85 \%$, mean of soil $\mathrm{pH} 7.3$, canopy opening $90-100 \%$ on the transect. Four species of termites were found, i.e., $S$. javanicus belonging to Family Rhinotermitidae, then O. javanicus, M. gilvus and $M$. insperatus belonging to Family Termitidae. Species $S$. javanicus is the only once belonging to Family Rhinotermitidae found. This species is wood feeder of lower termites, with the number of taxa lower than wood feeder of higher termites such as Termitidae, which is easily found in many kinds of habitat. Kambhampati and Eggleton (2000) state that Family Termitidae is the biggest family in the Order Isoptera and consist of $3 / 4$ of species of Isoptera known.

Table 2. Shannon-Wiener diversity index (H'), Shannon evenness index $€$ and Simpson dominance index (D) of termites in the karst area

\begin{tabular}{lccc}
\hline Altitudes & H' & E & D \\
\hline $0-500 \mathrm{~m}$ & 1.01 & 0.74 & 0.44 \\
\hline
\end{tabular}

Table 1. The abundance of each termite species in karst area of Southern Gombong, Central Java, Indonesia

\begin{tabular}{ccccc}
\hline $\begin{array}{l}\text { Altitudes } \\
\text { (m asl) }\end{array}$ & $\begin{array}{c}\text { Macrotermes } \\
\text { Gilvus }\end{array}$ & $\begin{array}{c}\text { Microtermes } \\
\text { insperatus }\end{array}$ & $\begin{array}{c}\text { Schedorhinotermes } \\
\text { javanicus }\end{array}$ & $\begin{array}{c}\text { Odontotermes } \\
\text { javanicus }\end{array}$ \\
\hline $0-100$ & 378 & 399 & 208 & 0 \\
$101-200$ & 443 & 141 & 118 & 0 \\
$201-300$ & 838 & 273 & 145 & 118 \\
$301-400$ & 238 & 16 & 102 & 102 \\
$401-500$ & 183 & 5 & 0 & 1374 \\
Abundance & 2680 & 834 & 670 & 10 \\
\hline
\end{tabular}




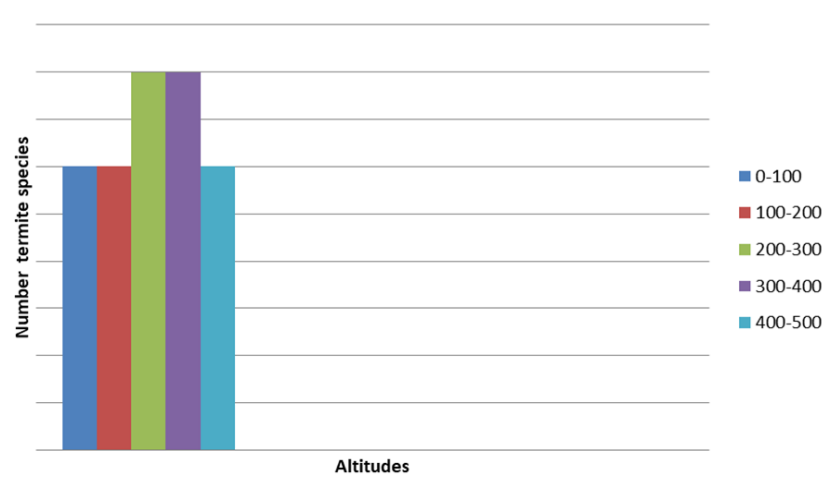

Figure 2. Number of termite species in each of altitudinal segment

This research found lower number of termite species than that in Mount Slamet with 11 species belonging to 9 genera (Pratiknyo et al. 2018). All of the species found in the karst hill were the wood-feeding termites, different from those found in Mount Slamet. The soil in karst area of Southern Gombong was presumably too dry for litter-or soil-feeding termites. Also, limestone in karst area is poor source of soil nutrients. The floor of teak forest in karst area with the canopy opening of $90-100 \%$ received direct sunlight for long time every day. There was no undergrowth vegetation such as found in forest in Mount Slamet. The humidity of the karst soil $60-75 \%$, while soilfeeding termites prefer wet soil with humidity $78-85 \%$ under the closed canopy. The floor of karst area forest was covered with dry teak leaves, but they had not been decomposed yet, which presumably were unpalatable for litter-feeding and soil-feeding termites, such as Procapritermes stiger, Pericapritermes javanicus, and genus Nasutitermes, found abundant in Mount Slamet forest.

The Shannon-Wiener diversity index (H') of termites in teak forest in the karst area was 1.01, categorized as low according to Odum and Barrett (2004). De Souza and Brown (1994) state that loose canopy is one of important factors affecting the diversity of termites in tropical forests. The Shannon-Evenness index (E) was 0.73 , categorized as moderately high. It means that the number of individuals among species did not differ much. In other words, no species dominated the community. As a result, the Simpson dominance index was relatively low, i.e., 0.44.

The regression between diversity of termites with altitude (100, 200, 300, 400 and $500 \mathrm{~m}$ ) showed low correlation $(\mathrm{R}=0,289)$. This was an interesting phenomenon, different from the result of similar research by Gathorny-Hardy et al. (2001) in primer forest in Leuser Aceh Province, showing that the termites diversity was strongly correlated negatively with altitudes. GathornyHardy et al. (2001) state that in tropical land forest, the increased altitude is the main factor that reduces the species diversity of termites because the increase of $100 \mathrm{~m}$ in altitude lowers the air temperature up to $1^{\circ} \mathrm{C}$. This research showed that the highest diversity of termites occurred in

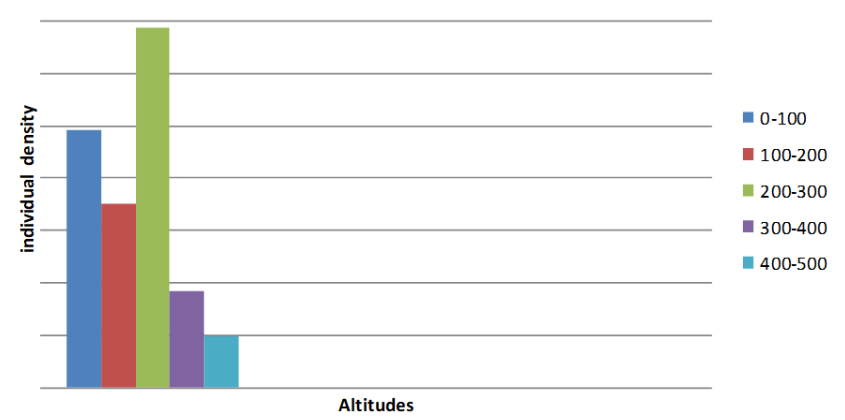

Figure 3. Termite individual density in each altitudinal segment in Karst area

mid altitudes of 200-300 $\mathrm{m}$ (Figures 2 and 3). This result is in line with that of Palin et al. ( 2011) and Lomolino (2001) that state that the pattern of diversity along altitudinal gradient follows the mid domain effect hypothesis, i.e., the highest diversity is found in mid altitudes. The result of this study was in line with that of Inoue et al. (2006) who found in national park of Khao Kitchagoot Thailand that the altitudes did not affect the diversity of termites linearly. Hermacandra (2003) states that people activities such as forest fragmentation and other activities reduce diversity of termites. The low diversity of termites on altitudes of 0-100 $\mathrm{m}$ was presumably due to its close distance to the people's settlement, so the people activities such as taking water, dry branches or litter under the forest possibly affect the termites' life. Meanwhile, the factor causing the low termite diversity in the top altitude, on $400-500 \mathrm{~m}$, was presumably the low volume of soil substrate because of $\mathrm{CaCO}_{3}$ limestone abundance with $\mathrm{pH}$ of 7.3 , whereas many species of termites especially the soil and litter feeders depend on simple sugar component from the soil substrate. Thus, the $\mathrm{CaCO}_{3}$ acts as a limiting factor for the termites.

Another interesting result of this research was the presence of $O$. javanicus on higher altitude of 200-500 m. Usually, the Subfamily of Macrotermitinae, such as $O$. Javanicus, prefer hotter air temperature $\left(24-28^{\circ} \mathrm{C}\right)$ with high relative air humidity $(90 \%)$ and areas with people activities. It is assumed that $O$. javanicus migrate passively by riding on the wood or bamboo used by the workers in lime mining area or brought accidentally by people who visited the old lime cave of Jatijajar tourism object.

The correlation between altitude and diversity of woodfeeding termites in South East Asia was stated by Inoue et.al (2006) that Subfamily Macrotermitinae showed increasing abundance with the increasing altitude. On the contrary, the abundance of Subfamily Nasutitermitinae decreases with the increasing altitude. Unfortunately the genus Nasutitermes was not found in karst area of Southern Gombong because in this teak forest which had opened canopy there was no lichen, the main diet of this genus. Setyawan (2000) states that lichens grow optimally under the closed canopy that prevents sunlight penetration, creating humid environment. 
Based on feeding habits, the termites found in the karst area of southern Gombong can be grouped into two groups, i.e., (i) the non-fungus-infected wood feeders (deadwood feeders), and (ii) the fungus-infected wood feeders (wood, litter, grasses and microepiphytes feeders). The first group was represented by $S$. javanicus, as stated by Faszly et al. (2005) that the genus of Schedorhinotermes consists of lower termites that consume dead wood materials, usually called as group I. The second group was represented by $O$. javanicus, M. gilvus, and $M$. insperatus. Food and Agriculture Organitation (2000) states that some species of termites belonging to subfamily Macrotermitinae, such as O. javanicus, $M$. gilvus, and $M$. Insperatus, show preference to the fungi of Termitomycetes. These fungi are an important component in the food chain for subfamily Macrotermitinae. In the karst area litter-feeding termites, such as Nasutitermes matangensis and $N$. matangensiformis were not found. Food and Agriculture Organitation (2000) states that food sources for genus Nasutitermes are wood, lichens, and humus. Soil-feeding termites such as Pericapritermes javanicus and Capritermes semarangi were not found either. Faszly et al. (2005) state that genera of Pericapritermes and Capritermes are the members of Family of Termitidae that consume soil only.

This study concluded that (i) the termite diversity in karst area at Southern Gombong was categorized as low, and no species dominated the area, and (ii) the highest diversity of termites was found in mid altitudes, in line with mid-domain effect hypothesis. We suggest that further research should be done in wet season to get comprehensive results.

\section{ACKNOWLEDGEMENTS}

We thank local BKPH Gombong Selatan for their kind cooperation. We are most grateful to Prof. Rifda Naufalin, the head of LPPM Unsoed, Purwokerto Utara, Indonesia for her support in funding the research.

\section{REFERENCES}

Abe T. Matsumoto T. 1979. Studies on the distribution and ecological role of termites in a low land rain forest of West Malaysia. Jpn J Ecol. 29: 337-351.

Ahmad M. 1958. Key to The Indomalayan Termites. Department of Zoology. University of The Punjabi, Lahore, Pakistan.

Bignell DE, Eggleton P. 2000. Termites in Ecosystems. Kluwer Academic, Dordrecht.

Carrijo TF, Brandao D, De Olivera DE, Costa DA, Santos T. 2009. Effect of pasture implantation on the termites (Isoptera) fauna in the Central Brazilian Savanna (Cerrado). J Insect Conserv 13: 575-581

Choosai C, Mathieu J, Hanboosong Y, Jouquet F. 2009. Termites mounds and dikes are biodiversity refuges in paddy fields in North-Eastern Thailand. J Environ Conserv 36: 71-79.

Collins NM. 1984. The Termite (Isoptera) of The Gunung Mulu National Park, with a key to the genera from Sarawak. Sarawak Museum J 30: 65-87.
Davies RG, Hernandes LM, Eggleton P, Didham RK, Fagn LL, Winchester NN. 2003. Environmental and spatial influence upon species composition of a termites assemblage across neotropical forest islands. J Tropic Ecol 19: 509-524.

De Souza OFF, Brown VK. 1994. Effects of habitat fragmentation on amazonian termite communities. J Tropic Ecol 10: 197-206.

FAO. 2000. Termite Biology and Management Workshop. Food and Agriculture Organization, Geneva.

Faszly R, Idris AB, Sajap AS. 2005. Termites (Insecta: Isoptera) Assemblages from Sungai Bebar Peat Swamp Forest, Pahang. Biodiversity Expedition Sungai Bebar, Pekan, Pahang. 4: 137-140.

Gathorne-Hardy FJ, Syaukani, Eggleton P. 2001. The effects of altitude and rainfall on the composition of the termites (Isoptera) of the Leuser ecosystem (Sumatra, Indonesia). J Tropic Ecol. 17: 379-393.

Grieco MAB, Cavalcante JJV, Cardoso AM, Vieira RP, Machado EA, Clementino MM, Medeiros MN, Albano RM, Garcia ES, de Souza W, Constantino R, Martins OB. 2009. Microbial Community Diversity in the gut of th South American Cornitermes cumulans (Isoptera: Termitidae). Bull Entomol Res. 99: 603-609.

Haneda, NF, Firmansyah, A. 2012. Keanekaragaman Rayap Tanah di Hutan Pendidikan Gunung Walat, Sukabumi. Jurnal Silvikultur Tropika 3: 92-96. [Indonesian]

Hemachandra IE. 2010. Distinctivenes of termite assemblages in two fragmented forest type in Hantane Hills in Kandy District of Sri Lanka. Cey J Sci (Biol Sci) 39 (1): 11-19

Inoue T, Takematsu Y, Yamada A, Hongoh Y, Johijima T, Moriya S, Somnuwat Y, Vongkaluang C, Ohkuma M, Kudo T. 2006. Diversity and abundance of termites along an altitudinal gradient in Khao Kitchagoot National Park, Thailand. J Tropic Ecol 22: 609-612.

Jones DT, Prasetyo AH. 2002. A Survey of The Termites (Insecta: Isoptera) of Tabalong District, South Kalimantan, Indonesia. Raffles Bull Zool 50: 117-128.

Jones DT, Eggleton P. 2000. Sampling termite assemblages in tropical forest: testing a rapid biodiversity assessment protocol. J Appl Ecol 37: 191-203.

Kambhampati S, Eggleton P. 2000.Taxonomy and Phylogeny of Termites In: Abe T, Bignell DE, Higashi M. (eds.). Termites: Evolution, Sociality, Symbiosis, Ecology. Kluwer Academic, Dordrecht.

Korb J, Linsmaier. 1998. The effect of temperature on the architecture and distribution of Macrotermes bellicosus (Isoptera. Macrotermitinae) mounds is different habitat of West African Guinea Savana. Insect Socoaux 45: 51-65.

Krebs CJ. 1989. Ecology The Experimental Analysis of Distribution and Abundance. 2nd ed. Harper and Row Publisher, New York.

Lee KE, Wood TG. 1971. Termites and Soil. Academic Press, London.

Lomolino MV. 2001. Elevation gradients of species density: Historical and prospective views. Global Ecol Biogeogr 10: 3-13.

Maguran AE. 1988. Principle of Ecology. Macmillan Press, London.

Odum EP, Barrett GW. 2004. Fundamentals of Ecology. 5th ed. Cengage Learning, New York.

Palin OF, Eggleton P, Malhi Y, Gerardin CAJ, Cavilla AR, Parr CL. 2011. Termites diversity along an Amazon-Andes elevation gradient, Peru. Biotropica. 40: 100-107.

Pratiknyo H, Ahmad I, Budianto BH. 2018. Diversity and abundance of Termites along altitudinal gradient and slopes of Mount Slamet Central Java, Indonesia. Biodiversitas 19 (5): 1649-1648

Pribadi T, Rafiudin R, Harahap IS. 2011. Termites community as environmental bioindicator in highland: A case study in eastern slope of Mount Slamet, Central Java. Biodiversitas. 12 (3): 235-240.

Setyawan AD. 2000. Epiphytic plants on stand of Schima wallichii (D.C.) Korth. at Mount Lawu. Biodiversitas 1 (1): 14-20. [Indonesian]

Vaessen T, Verwer C, Damies M, Kaliang H, Van Der Meer PJ. 2011. Comparison of termite assemblages along a land-use gradient on peat areas in Sarawak, Malaysia. J Trop For Sci. 23: 196-203.

Wood TG, Sands WA. 1978. The role of termites in ecosystem. In: Brian MV (ed.) Production ecology of ant and termites. Cambridge University Press, Cambridge.

Yamada A, Inooue T, Wiwatwitaya D, Ohkuma M, Kudo T, Abe T, Susimoto A. 2005. Carbon mineralization by termites in tropical forest, with emphasis on fungus-comb. Biol Res 20: 453-460. 